\title{
03213 多連秤を用いた高精度質量計測 \\ Precise Mass Measurement using Multi-stage Conveyor Belt Scales
}

\author{
○山崎 敬則·(小山高専） 田崎 良佑 (小山高専) 大西 秀夫（新光電子） \\ 小林、政明（新光電子）。黒須茂（クロテック）
}

Takanori YAMAZAKI, Ryosuke TASAKI, Oyama National College of Technology, 771 Nakakuki, Oyama, Tochigi Hideo OHNISHI, Masaaki KOBAYASHI, Shinko Co., Ltd.

Shigeru KUROSU,'Research Inst. Crotech.

\begin{abstract}
In the automatic weighing of packages in motion, the sequence of products is generally completely random. Long, short, heavy and light products are passed over the conveyor belt scale in any kind of random sequence. Through the multi-stage conveyor belt scale, a weighing scale can be created which will adjust the conveyor belt length to the product length. Our interest is directed to solve many technical problems when we put the multi-stage conveyor into practical use. Consequently, our weighing algorithm proposed here will give us an accurate and desirable performance with the possible improvements.
\end{abstract}

Key words: Mass Measurement, Conveyor Belt Scale, Multi-stage Measurement

1. はじめに

著者らは,・コンベアライン上で搬送される秤量物の長さ が計量コンベアの長さより短い場合について, FIRフィルタ で平滑化した測定データの最大值から秤量物の質量を推定 する簡易測定法を提案している ${ }^{1), 2)}$. 様々な長さや質量の秤 量物が連続的に搬送される状況で，コンベアラインを停止 させずに高精度で質量を測定する方法として, 複数の計量 コンベア（多連秤）を配置し，その出力を組み合せた多連 秤による質量測定がすでに実用化されている ${ }^{3)}$ が多連秤の 性能には, 益々厳しい要求が課せられつつある。メーカ側 では主としてハードウェアの改良に力が注がれているよう である.そこで本研究では，多連秤による質量測定を信号 処理として捕らえ, ソフトウェアの側面から数理的に検討 している.

\section{2. 計測システムの概要}

コンベアライン上で搬送されるダンボール箱に装てんさ れた様々な長さや質量の秤量物の質量を連続的に計測する システムを考える. 計測システムの基本的な構成の概略を 図 1 に示す。ここで, $l_{i}$ : 秤量物の長さ $(\mathrm{cm}), L_{i}$ : 計量コン ベアの長さ $(\mathrm{cm}), d_{i}$ : 連続した秤量物の間隔 $(\mathrm{cm}), v:$ : コン ベアの搬送速度 $(\mathrm{m} / \mathrm{s})$ である.

荷重受部は 1 点でロードセルによって支持されたベルト コンベア（計量コンベア）であり，これを複数配置して多 連秤を構成する. 秤量物が計量コンベアに載ると, 搬入側 に取り付けられた光電スイッチが働き, 計測が開始される. 秤量物の通過する時間内に荷重がロードセルによって検知

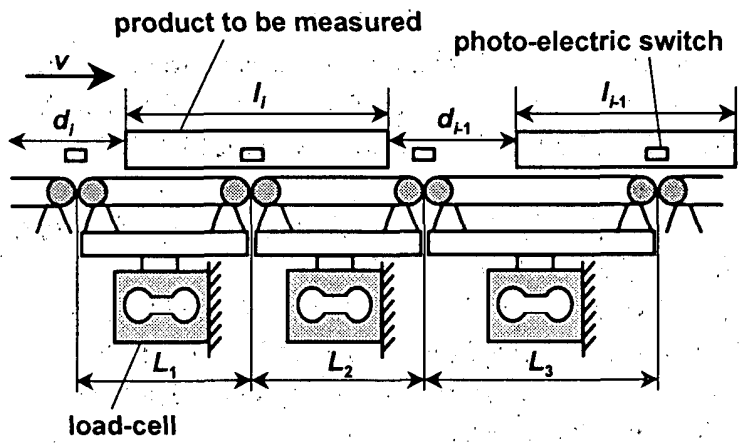

Fig. 1 Multi-stage conveyor belt scale
され電圧信号と.して取り出される. 電圧信号は A/D 変換を 通してパソコンへ送られる。パソコンではFIRフィルタの アルゴリズムによって高周波成分が除去され，過渡応答の 形状から秤量物の質量が推定される.

\section{3. 幾何学的な測定条件}

Fig.1において, $l_{i} \leqq L_{1}, L_{2}, L_{3}$ である場合に，単体の計量 コンベア（単連秤という）に印加される入力荷重 $m_{i}$ の時間 的変化を示したのが Fig.2である. 同様に, $l_{i} \geqq L_{1}, L_{2}, L_{3}$ で ある場合に，三連秤での印加される入力荷重 $m_{i}$ の時間的変 化を示したのが Fig.3である.

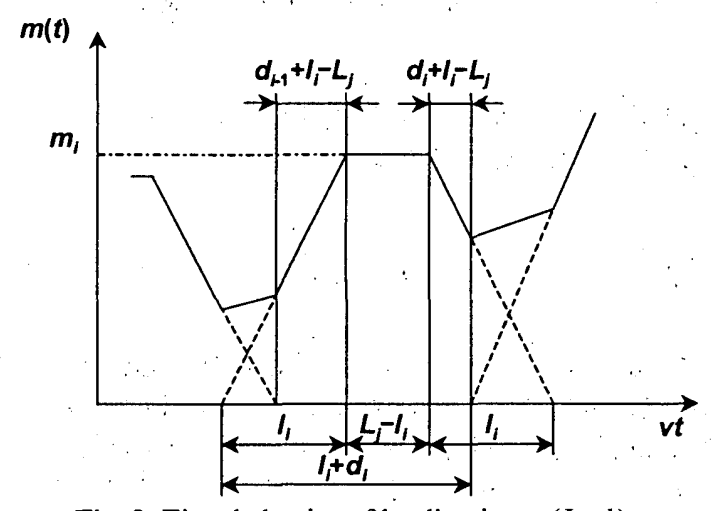

Fig. 2 Time behavior of loading input $\left(L_{j}>l_{i}\right)$ (for a single-stage conveyor belt scale)

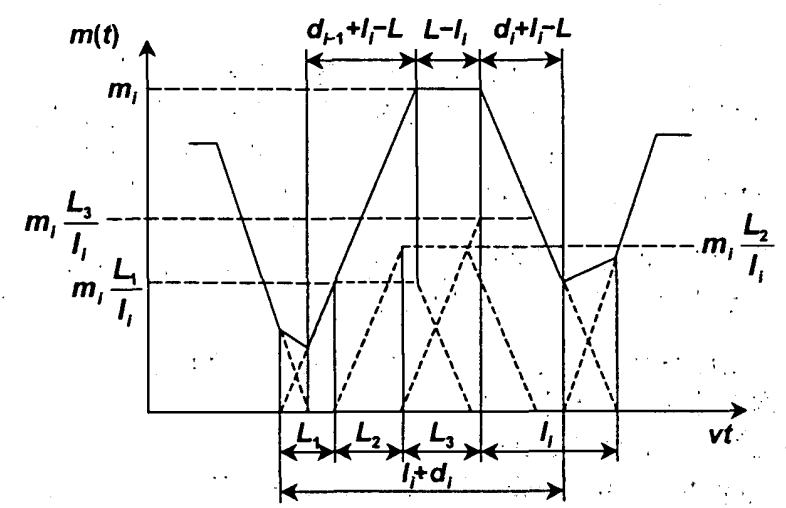

Fig. 3 Time behavior of loading input $\left(L_{j}<l_{i}\right)$ (for a three-stage conveyor belt scale)

日本機械学会関東支部第 10 期総会講演会講演論文集〔'04-3.4〜6,東京〕 

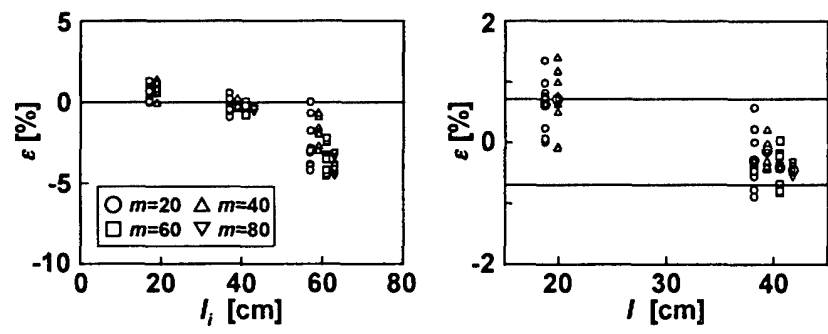

Fig. 4 Distributions of estimation errors (for a single-stage conveyor belt scale)
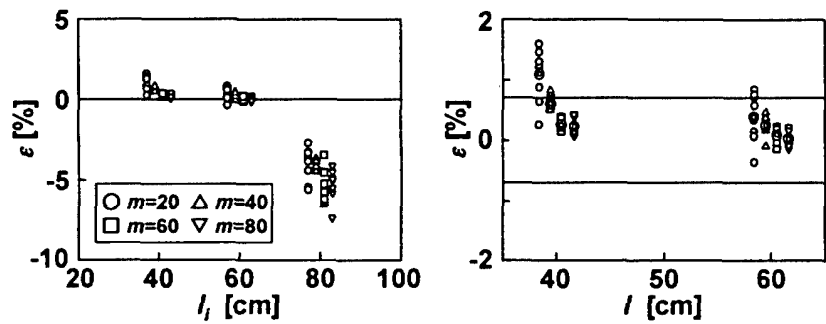

Fig. 5 Distributions of estimation errors (for a two-stage conveyor belt scale)
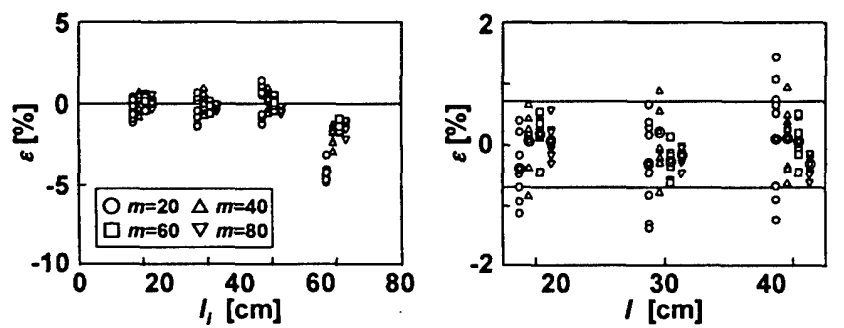

Fig. 6 Distributions of estimation errors (for a three-stage conveyor belt scale)

Fig. 2,3より，連続秤量する場合に秤量物長さ $l_{i}$ の質量 $m_{i}$ を測定できる条件はつぎのように書ける.

$$
\begin{aligned}
& d_{i-1}>L-l_{i}>0 \\
& d_{i}>L-l_{i}>0
\end{aligned}
$$

ここで, $d_{i-1}, l_{i}, d_{i}$ は光電スイッチの遮光から透光に, 透光 から遮光に移行する時間間隔によって逐次計測される. (1) 式の物理的意味は, 秤量物の長さ $l_{i}$ と前後の秤量物との間隔 $d_{i-1}, d_{i}$ を加えた長さが, 計量コンべアの長さの合計 $L$ より 大きくなければならないことである。ここで $L$ は，単連秤 では $L=L_{3}$, 二連秤では $L=L_{1}+L_{2}$, 三連秤では $L=L_{1}+L_{2}+L_{3}$ と している.

\section{4. 多連秤による測定結果}

多連秤による実際の測定に際して，数学モデルを用いた シミュレーションを行った結果，それぞれの秤の測定範囲 について次の知見を得た。

単連秤では $l_{i} \leqq 40[\mathrm{~cm}]$, 二連秤では $40<l_{i} \leqq 60[\mathrm{~cm}]$, 三連秤では $60<l_{i} \leqq 125[\mathrm{~cm}]$

以上の考察のもとに, 多連秤による測定実験を実施した． 搬送条件はつぎのとおり。

単連秤 $\left(L=L_{3}=60[\mathrm{~cm}]\right)$

$l_{i}=20 \sim 60[\mathrm{~cm}], \quad m_{i}=20 \sim 80[\mathrm{~kg}], d_{1}=d_{2}=100[\mathrm{~cm}]$,

\begin{tabular}{|c|c|c|c|}
\hline $\begin{array}{l}\text { conveyor } \\
\text { belt scale }\end{array}$ & $\begin{array}{l}\text { length } \\
\text { of product } \\
\text { [cm] }\end{array}$ & $\begin{array}{c}\text { mean } \\
\text { value of } \varepsilon \\
{[\%]}\end{array}$ & $\begin{array}{c}\text { standard } \\
\text { deviation of } \varepsilon \\
{[\%]}\end{array}$ \\
\hline \multirow{2}{*}{$\begin{array}{l}\text { single- } \\
\text { stage }\end{array}$} & $1=\mathbf{2 0}$ & 0.66 & 0.46 \\
\hline & $I=40$ & -0.25 & 0.41 \\
\hline \multirow{2}{*}{$\begin{array}{l}\text { two- } \\
\text { stage }\end{array}$} & $1=40$ & 0.55 & 0.42 \\
\hline & $I=60$ & 0.15 & 0.28 \\
\hline \multirow{3}{*}{$\begin{array}{l}\text { three- } \\
\text { stage }\end{array}$} & $1=80$ & -0.0044 & 0.44 \\
\hline & $t=80$ & -0.18 & 0.46 \\
\hline & $l=120$ & -0.0047 & 0.57 \\
\hline
\end{tabular}

Table 1 Mean estimation errors and standard deviations

二連秤 $\left(L=L_{1}+L_{2}=80[\mathrm{~cm}]\right)$

$l_{i}=40 \sim 80[\mathrm{~cm}], \quad m_{i}=20 \sim 80[\mathrm{~kg}], d_{1}=d_{2}=100[\mathrm{~cm}]$,

三連秤 $\left(L=L_{1}+L_{2}+L_{3}=140[\mathrm{~cm}]\right)$

$l_{i}=80 \sim 140[\mathrm{~cm}], \quad m_{i}=20 \sim 80[\mathrm{~kg}]$.

ここで, 単連秤と二連秤では同じ秤量物を 3 個連続して搬 送している，三連秤では測定不能となる場合が生じ，単体 で搬送したので $d_{1}, d_{2}$ の記述はない.

秤量物の長さ $l_{i}$, 秤量物の質量 $m_{i}$ について測定点は 9 点で ある. 単連秤, 二連秤, 三連秤による誤差率 $\varepsilon$ の分布をそれ ぞれFig.4 6に示す. なお, 右図は左図の拡大図で, 拡大図 中の二重丸は，それぞれの誤差率 $\varepsilon$ の平均值 (平均誤差率) を示している. 各長さ $l_{i}$ に関して平均誤差率と標準偏差とを 算出した結果を Table 1 に示す.これらの結果から,つぎの ことがわかる。

1) 単連秤では $l_{i} \leqq 40[\mathrm{~cm}]$, 二連秤では $l_{i} \leqq 60[\mathrm{~cm}]$, 三連秤 では $l_{i} \leqq 120[\mathrm{~cm}]$ のき, 平均誤差率 $\bar{\varepsilon}$ が $0.7 \%$ 以下を満 たしている。

2) 誤差率 $\varepsilon$ の分布状況は, 質量 $m_{i}$ が大きいほど狭くなって いる.

\section{5. おわりに}

本研究では,コンベアライン上に搬送される秤量物の質量 を高速, 高精度で測定するために, 複数の計量コンベアの出 カを組み合せた多連秤による連続科量をソフトウェアの側面 から数理的に検討している.

本研究の成果をまとめると，つぎのようになる.

1) 多連秤によって秤量物の質量を連続測定するさいに, 計測 可能となる幾何学的条件を示した.

2) 秤量物の長さ 20 140[cm]に対して単連，二連，三連秤に よる連続秤量を実施し，平均誤差率 $0.7 \%$ 以下が保証され る条件を明らかにした。

3) 本研究で提案した多連秤による簡易測定法が実用性のある ことが明らかとなった。

\section{参考文献}

1) T.Yamazaki, et al.: Continuous Mass Measurement in Checkweighers and Conveyor Belt Scales, Proceedings of IMEKO TC3/TC5/TC20, Celle in Germany 295/301 (2002)

2) 野田, 桜井, 山崎, 大西, 小林, 黒須: コンベアライン 上での連続秤量における精度の向上, 計測自動制御学 会論文集 38-9, 759/764 (2002)

3) 公開特許公報: 特開平10-122940, 特許第3249055号 (2001) European Patent Application : EP0953828A1 (1999) OCS In-Motion Scales: OCS Checkweigher GmbH(Germany), Post-Expo 2002 (2002) 